\title{
ANALISIS FAKTOR-FAKTOR YANG MEMPENGARUHI KEPUTUSAN PEMBELIAN PADA MAHASISWA BERKEBUTUHAN KHUSUS
}

\author{
Oleh: \\ Rahma Nur Praptiwi ${ }^{1}$ \\ Sri Isti Untari ${ }^{2}$ \\ Program Studi Manajemen Pemasaran \\ Politeknik Negeri Jakarta \\ Email: \\ rahma.nurpraptiwi@mp.pnj.ac.id
}

\begin{abstract}
ABSTRAK
Para pihak pelaku usaha melaksanakan kompetisi yang sangat kera guna menarik simpati dari pihak konsumen. Sebagian konsumen yaitu sekitar 24 juta penduduk Indonesia adalah Warga Negara Berkebutuhan Khusus atau disabilitas. Individu dengan hambatan intelektual mempunyai keterbatasan dalam hal fungsi di dalam adaptif dan juga fungsi dalam pikir, hal ini disebabkan oleh tingkatan dari kecerdasannya yang pada umumnya di bawah rata-rata. Hal itu tampak dalam keterbatasan mereka ketika berkomunikasi dan dalam keterampilan bersosialisasi. Program Studi (Prodi) Manajemen Pemasaran untuk Warga Negara Berkebutuhan Khusus (MP-WNBK) Politeknik Negeri Jakarta (PNJ) memfasilitasi individu dengan disabilitas untuk dapat turut mendapatkan pendidikan vokasional tingkat diploma. Tujuan dari pelaksanaan penelitian ini ialah guna melaksnakan penganalisisan berkenaan dengan pengaruh dari faktor-faktor yang memberikan sumbangan pengaruh pada keputusan pembelian pada keputusan pembelian produk pada WNBK. Metode yang dipergunakan di dalam pelaksanaan penelitian ialah observasi dan kuesioner. Lokasi penelitian di Program Studi MP-WNBK PNJ dengan membuat ruangan simulasi yang berisi rak-rak berisi aneka produk minuman dalam kemasan. Hasil penelitian menunjukkan faktor pengambilan keputusan bagi Warga Negara Berkebutuhan Khusus adalah faktor psikologi dan faktor sosial.
\end{abstract}

Kata Kunci: pengambilan keputusan, warga berkebutuhuhan khusus 


\section{A. PENDAHULUAN}

Pada umumnya manusia pernah membeli barang. Biasanya konsumen untuk memperoleh atau mendapatkan barang sudah melewati beberapa tahap, misalnya ialah mencari informasi dengan mempergunakan beberapa sumber informasi, lalu mengkomparasikan barang tertentu dengan barang lainnya hingga pada waktunya konsumen tersebut melaksanakan keputusan untuk mempergunakan atau mengurangi nilai guna barang tersebut. Pencarian informasi tersebut membutuhkan pemikiran dan analisis, sedangkan keterbatasan yang dialami oleh penyandang disabilitas salah satunya adalah keterbelakangan mental yang memiliki keterbatasan fungsi pikir. Hal ini seyogyanya mempengaruhi pengambilan keputusan ketika memilih produk. Masalah ini menarik untuk diteliti, karena sekitar 24 juta penduduk Indonesia adalah disabilitas.

Menurut penghitungan WHO, disabilitas di Indonesia diperkirakan 10 persen (24 juta) dari populasi. Salah satu disabilitas adalah keterbelakangan mental. Individu dengan hambatan intelektual mempunyai keterbatasan dalam hal fungsi di dalam adaptif dan juga fungsi dalam pikir, hal ini disebabkan oleh tingkatan dari kecerdasannya yang pada umumnya di bawah rata-rata. Hal itu tampak dalam keterbatasan mereka ketika berkomunikasi dan dalam keterampilan bersosialisasi.

Program Studi (Prodi) Manajemen Pemasaran untuk Warga Negara Berkebutuhan Khusus (MP-WNBK) Politeknik Negeri Jakarta (PNJ) memfasilitasi individu dengan disabilitas untuk dapat turut mendapatkan pendidikan vokasional tingkat diploma. Peserta didik Prodi MP-WNBK Politeknik Negeri Jakarta saat ini terdiri atas 77 mahasiswa aktif dengan beragam disabilitas, di antaranya gangguan pendengaran (tunarungu), attention deficit hyperactivity disorder (ADHD), celebral palsy, down syndrome, autism spectrum disorder (ASD), slow learner, disleksia, dan diskalkulia. Tujuan dari pelaksanaan penelitian ini ialah guna memahami faktor-faktor yang memberikan sumbangan pengaruh pada keputusan untuk melaksanakan pembelian terhadap produk yang ada pada WNBK.

\section{B. KAJIAN PUSTAKA}

\section{Definisi Disabilitas}

Sering kali ditemukan bahwa penyandang disabilitas dipandang sebagai penyandang disabilitas fisik saja. Padahal istilah disabilitas juga meliputi disabilitas nonfisik. Di dalam Undang-Undang Republik Indonesia No. 8 Tahun 2016 tentang Penyandang Disabilitas, pada Bab 1 Pasal 1 dirujuk dalam (Widinarsih, 2019) menjelaskan bahwa orang yang menyandang disabilitas ialah orang yang menderita kekurang dalam hal sensorik, mental, intelektual dan juga fisik untuk waktu yang panjang dalam melaksanakan aktivitas interaksi terhadap lingkungan dan menimbulkan kendala dan kesulitan guna ikut ambil bagian secara efektif dan penuh dengan masyarakat yang lainnya merujuk pada persamaan hak yang ada.

Di dalam pasal 4 ayat 1 dirujuk dalam (Widinarsih, 2019) mendefinisikan bahwa ragam penyandang disabilitas mencakup:

a. Penyandang disabilitas dalam bentuk fisik ialah terdapat gangguan terhadap fungsi gerak dari seorang individu, misalnya ialah orang kecil, akibat kusta, 
akibat stroke, celebral palsy (CP), paraplegi, kaku atau lumpuh layuh, dan juga amputasi.

b. Penyandang disabilitas dalam bentuk intelektualitas ialah terdapat gangguan terhadap fungsi dalam hal berfikir, sebab tingkatan kecerdasan yang ada ialah di bawah standar atau rata-rata, misalnya ialah down syndrome, lambat belajar dan juga disabilitas grahita.

c. Penyandang disabilitas dalam bentuk mental ialah terdapat gangguan terhadap fungsi dalam hal perilaku, pikir, dan juga emosi, diantaranya ialah: psikososial (gangguan kepribadian, anxietas, depresi, bipolar, dan juga skizofrenia) dan juga disabilitas perkembangan yang memberikan sumbangan pengaruh terhadap kapasitas dalam melaksanakan interaksi sosial (hiperaktif dan autis).

d. Penyandang disabilitas dalam bentuk sensorik ialah terdapat gangguan terhadap fungsi dalam hal panca indera, diantaranya ialah disabilitas wicara, disabilitas netra, dan juga disabilitas rungu.

\section{Keputusan Pembelian}

Setiadi (2012:251) pada (Dewanto et al., 2018) menjelaskan bahwa keputusan pembelian ialah sebuah proses dalam menyelesaikan permasalahan yang isinya ialah pengenalan dan penganalisisan berkenaan dengan keinginan dan juga kebutuhan, melaksanakan pengindentifikasian informasi, melaksanakan penilaian terhadap sumber-sumber pilihan dalam hal alternatif atau pilihan pembelian. Kotler (2011:144) pada (Amri, 2018) menjelaskan bahwa perilaku di dalam pembelian yang dilaksankan oleh konsumen dipengaruh dengan beberapa faktor, diantaranya ialah faktor psikologis, faktor pribadi, faktor sosial, dan juga faktor budaya.

Menurut (Dewanto et al., 2018) menjelaskan bahwa faktor Psikologis Pribadi, Sosial, dan Budaya memberikan sumbangan pengaruh pada keputusan dalam melaksanakan pembelian terhadap kendaraan bermotor dari brand Yamaha yang ada pada Lingkungan dari Fakultas Ekonomi dan Bisnis UNSRAT. Menurut (Pinem, 2018) merujuk pada analisa faktor-faktor yang mempengaruhi tersebut dihasilkanlah suatu hasil penelitian bahwa terdapatnya enam faktor yang memberikan sumbangan pengaruh pada keputusan dalam melaksanakan pembelian minyak goreng untuk kemasan dari brand Bimoli. Keenam faktor itu diantaranya ialah Kepercayaan Pribadi, Pengaruh Lingkungan, Gaya Hidup, Sosial, Psycho Demografis, dan juga Psycho Sosiologis. Hasil dari pelaksanaan penelitian yang dilaksanakan (Saerang et al., 2017) menjelaskan bahwa persepsi harga dan juga mutu dari barang memberikan sumbangan secara simultan pada keputusan dalam melaksanakan pembelian untuk barang speaker dari brand Yamaha yang ada pada di Fortino Audio Manado. Sedangkan kesimpulan pada penelitian (Karosekali \& Natasha, 2018) menyebutkan bahwa faktor-faktor tersebut ialah Self Confidence, Family Scope, dan juga Social Environment. Faktor utama dalam memberikan sumbangan pengaruh pada pembelian brand dari Filma ialah Social Environment.

Penelitian (Mindari, 2020) menjelaskan bahwa di dalam hasil dari penelitian memperlihatkan bahwa keputusan dalam melaksanakan pembelian untuk barang roti yang berisikan dengan krim durian yang terjadi pada Desa Rantau Sialang Kecamatan Sungai Keruh disebabkan atau diprediksikan secara simultan oleh 
faktor psikologis, faktor pribadi, faktor sosial, dan juga faktor budaya. Akan tetapi, dalam keadaan parsial hanya dipengaruhi signifikan oleh faktor psikologis, faktor sosial, dan juga faktor pribadi. Sementara itu merujuk pada hasil simpulan dari penelitian yang dilaksanakan (Ruhamak, 2016) menjelaskan bahwa secara simultan bahwa faktor psikologis, faktor pribadi, faktor sosial dan faktor budaya memberikan sumbangan pengaruh signifikan pada keputusan untuk melakukan pembelian terhadap produk air minum bermerk AQUA. Faktor psikologi memberikan sumbangan pengaruh signifikan pada keputusan untuk melakukan pembelian terhadap produk air minum bermerk AQUA.

Berdasarkan pada hasil dari penelitian yang dilaksanakan (Firman maulana, 2016) memperlihatkan bahwa tindakan pengambilan suatu keputusan dalam melakukan pembelian yang berlangsung di pasar tradisional itu diprediksikan atau disebabkan oleh beberapa faktor, diantaranya ialah faktor kebutuhan yang berasal dari budaya dan juga fisiologis. Penelitian (Timmerman et al., 2017) menyimpulkan faktor yang berasal dari kebudayaan memberikan sumbangan pengaruh yang positif pada proses dari keputusan untuk melakukan pembelian pada produk Texas Chiken Cabang Manado. Kesimpulan penelitian (Suawa et al., 2019) komposisi faktor psikologis mempengaruhi konsumen dalam melakukan pembelian di New Ayam Bandung.

Kesimpulan penelitian (Prabowo, 2017) menjelaskan bahwa perilaku yang ditunjukkan oleh konsumen dalam melangsungkan tindakan pembelian terhadap produk notebook diprediksikan atau disebabkan oleh beberapa faktor, diantaranya ialah faktor psikologi dan juga faktor ekonomi. Menurut (Yusra Mauliza Nasution, Iskandarini, 2018) menyebutkan bahwa variabel dari faktor psikologi, faktor pribadi, faktor sosial, dan juga faktor budaya memberikan sumbangan pengaruh yang signifikan secara simultan pada variabel dependen dari keputusan untuk melakukan tindakan pembelian terhadap produk telur Omega-3. Sementara itu, untuk variabel dari faktor psikologi dan budaya memberikan sumbangan pengaruh signifikan secara parsial pada variabel terikat dari keputusan untuk melakukan pembelian dari produk telur premium Omega-3. Menurut (Arbana Syamantha, 2018) menjelaskan bahwa tiap masyarakat memiliki kebudayaan dan pengaruh dari kebudayaan tersebut dalam melaksanakan tindakan pembelian sangat berbedabeda, dengan demikian distributor barang akan berupaya untuk mengidentifikasikan perubahan kebudayaan, dengan demikian bisa memahami produk yang baru yang kemungkinan yang diperlukan dan dibutuhkan oleh masyarakat yang berperan sebagai konsumen.

Kesimpulan hasil penelitian (Ismunandar, 2019)faktor budaya berkorelasi positifdengan keputusan untuk melakukan pembelian Lo'i Mee Mbojo yang berlangsung pada Kota Bima. Menurut (Natanael, 2020) menyebutkan bahwa faktor-faktor, antara lain faktor psikologi, faktor pribadi, faktor sosial dan juga faktor budaya memberikan sumbangan pengaruh signifikan dan positif pada variabel keputusan untuk melaksanakan pembelian terhadap smart phone Xiaomi generasi Y yang terjadi di kota Surabaya. Sedangkan menurut (Sari, 2016) menyebutkan bahwa terdapat beberapa faktor, antara lain faktor pribadi, faktor budaya dan faktor sosial memberikan sumbangan pengaruh secara simultan pada 
variabel dependen, yakni keputusan untuk melaksanakan pembelian yang berlangsung di Rumah Makan Mas Demang.

\section{METODE PENELITIAN}

Penelitian ini termasuk penelitian kuantitatif. Contoh adalah mahasiswa untuk Program Studi Manajemen Pemasaran untuk Warga Negara Berkebutuhan Khusus Politeknik Negeri Jakarta. Contoh akan diambil sebanyak 40 orang. Penarikan contoh dilakukan secara judgement sampling, yaitu dipilih berdasarkan pertimbangan peneliti. Guna memperoleh data yang diperlukan di dalam pelaksanaan penelitian, dilakukanlah proses pengempulan data dengan cara mengidentifikasi penelitian di lapangan dan juga penelitian berkenaan dengan studi kepustakaan. Penelitian ini dilaksanakan dengan turun langsung pada objek penelitian. metode yang dipergunakan ialah terdapat dua jenis pengumpulan data, yakni dengan cara melaksanakan penyebaran angket kuisioner dan juga melaksanakan aktivitas pengobservasian.

Observasi didefinisikan sebagai suatu pelaksanaan pengamatan pada kondisi dan fenomena yang benar-benar terjadi pada lokasi dari penelitian secara langsung. Lokasi penelitian adalah ruang konsultasi pada Gedung Arsip Politeknik Negeri Jakarta Program Studi Manajemen Pemasaran untuk Warga Negara Berkebutuhan Khusus. Lokasi penelitian ini dipilih berdasarkan pertimbangan keamanan dan kemudahan akses. Ruang konsultasi memiliki beberapa rak yang untuk sementara dibuat rak seperti minimarket. Produk yang dipajang hanya produk minuman dalam kemasan. Metode observasi dipilih untuk melihat langsung bagaimana cara mereka memilih dan mengambil keputusan dalam pembelian sebuah produk. Contoh adalah Warga Negara Berkebutuhan Khusus dengan tipikal keterbelakangan mental yang membutuhkan tindakan konkrit, sementara itu untuk definisi dari kuisioner diartikan dengan suatu proses dalam pelaksanaan pengumpulan data dengan cara memberikan atau menyebarkan berbagai atau beberapa daftar pernyataan atau pertanyaan pada konsumen dari suatu produk tertentu yang dijadikan sebagai responden penelitian guna dijawab dan diisi berdasarkan pada kondisi yang benarbenar yang sedang dialami atau terjadi, dengan demikian dihasilkanlah informasi berkenaan dengan tingkat keabsahan dan kesahihan data sebaik-baiknya.

Disain penelitian di dalam pelaksanaan penelitian ini ialah cross sectional study, yakni data yang dilaksanakan pengumpulan untuk periode waktu tertentu dan tidak berkesinambungan. Penelitian ini termasuk penelitian kuantitatif. Analisis deskriptif yang dipergunakan diantaranya ialah tabulasi silang dan juga sebaran frekuensi. Sementara itu, analisis inferensial yang dipergunakan ialah analisis faktor faktor. Menurut (Pinem, 2018) tujuan penggunaan analisis faktor ialah guna memahami struktur variable yang sedang dilaksanakan penelitian. Analisis faktor di dalam pelaksanaan penelitian ini dipergunakan guna melaksanakan pengidentifikasian terhadap faktor-faktor yang memberikan sumbangan pengaruh pada keputusan dalam melaksanakan pembelian yang dilakukan oleh konsumen. 


\section{HASIL DAN PEMBAHASAN}

\section{Gambaran Umum Lokasi Penelitian}

Manajemen Pemasaran ialah salah satu dari beberapa program studi yang tersedia pada Politeknik Negeri Jakarta (PNJ). Program studi ini berdiri atas mandat MENRISTEKDIKTI melalui SK Mandat No.549/E/T/2011 dan SK DIRJEN DIKTI No.96/E/0/2013, ditujukan untuk dapat menjadi wadah bagi warga negara berkebutuhan khusus lulusan SMA/SMK Luar Biasa dan/atau inklusi agar bisa meneruskan ke jenjang pendidikan tinggi khususnya di bidang Manajemen Pemasaran (MP). Warga Negara Berkebutuhan Khusus (WNBK) yang dapat mendaftar ke MP tidak diberi batasan, seperti kecenderungan gifted, autis high functioning, autis low functioning, keterbatasan fisik (tuna daksa, tuna rungu dan juga tuna wicara), disabilitas intelektual (ringan, sedang, dan berat), tuna ganda (gabungan dari dua atau lebih keterbatasan). Hanya saja yang dapat diterima sebagai mahasiswa ialah terbatas pada pendaftar dengan predikat lulus seleksi. Sebagai konsekuensi logis atas kondisi tersebut, Prodi MP perlu dirancang secara khusus dengan sarana dan prasarana yang bisa mendukung berlangsungnya proses pembelajaran berdasarkan pada keadaan dari warga negara berkebutuhan khusus.

\section{Karakteristik Responden}

Karakteristik dari responden penelitian mencakup jenis produk yang dipilih, uang saku per bulan, usia, dan juga jenis kelamin. Tujuan diperlukannya karakteristik data adalah untuk mengidentifikasi karakteristik konsumen yaitu mahasiswa program studi Manajemen Pemasaran untuk Warga Negara Berkebutuhan Khusus Politeknik Negeri Jakarta.

Kisaran tentang jenis kelamin responden sebagian besar $(82.5 \%)$ adalah berjenis kelamin laki-laki. Rentang usia responden adalah 18 sampai 24 tahun dengan jumlah paling banyak ialah berusia 20 tahun dengan persentase sebanyak $25 \%$. Hampir separuh (42.5\%) uang saku responden berada di taksiran Rp 500.000Rp 1.000 .000 , selanjutnya sebanyak $20 \%$ responden penelitian mempunyai uang saku dengan kisaran $<\mathrm{Rp} 500.000$ dan $\mathrm{Rp} 1.000 .001-\mathrm{Rp} 2.500 .000$. terdapat sekitar $12.5 \%$ responden responden penelitian tersebut memilki uang saku senilai Rp 2.500.001-Rp 5.000.000 dan sebesar 5\% responden penelitian mempunyai uang saku lebih dari Rp 5.000.000 per bulan. Jenis produk yang dipilih untuk hamper separuh responden $(42.5 \%)$ adalah produk minuman teh dalam kemasan.

\section{Pengambilan Keputusan Pembelian Produk}

Hampir seluruh responden (95\%) memilih produk minuman dalam kemasan karena yakin mutu dari produk tersebut bagus. Hal demikian memperlihatkan bahwa responden yakin bahwa produk yang dipilih merupakan kebutuhannya. Hampir seluruh responden (95\%) mempunyai kesan yang baik dari informasi yang di dapat terhadap produk yang dipilih. Hal ini menunjukkan bahwa responden menerima informasi yang cukup tentang produk yang dipilih. Informasi yang didapat oleh responden berasal dari keluarga, teman, sosial media, promosi produk ke sekolah, dan kegiatan yang di sponsori produk ketika responden masih duduk di bangku SMA. 
Hampir seluruh responden $(95 \%)$ memilih produk karena menyukai rasa produk yang dipilih. Sebagian besar responden $(87.5 \%)$ pernah membeli sebelumnya dan menyukai produk yang dipilih tersebut. Sebagian besar responden $(75 \%)$ biasa membeli produk tersebut dalam keseharian. Merujuk pada data-data yang disajikan tersebut bisa dihasilkan suatu simpulan bahwa produk yang dipilih ialah suatu produk yang disukai dan dibeli oleh konsumen pada umumnya.

Sebagian kecil responden (35\%) membeli produk minuman dalam kemasan dimana saja ketika haus. Lebih dari separuh responden $(65 \%)$ membeli produk minuman dalam kemasan hanya di tempat-tempat tertentu seperti minimarket atau supermarket. Alasan dari responden lebih memilih membeli produk minuman dalam kemasan di minimarket atau supermarket antara lain faktor kenyamanan, harga yang diyakini lebih murah, dan sepertinya dikarenakan uang saku yang cukup bahkan lebih dari cukup.

Lebih dari separuh responden (55\%) memilih produk yang biasa dikonsumsi oleh keluarganya. Sedangkan sebagian kecil responden $(35 \%)$ memilih produk karena pengaruh teman. Lebih dari separuh responden $(65 \%)$ memilih produk karena melihat iklan di sosial media. Data ini menunjukkan bahwa pemilihan produk lebih dipengaruhi oleh iklan di sosial media dan kebiasaan keluarga dibandingkan ajakan teman. Hal ini mungkin disebabkan karena responden adalah Warga Negara Berkebutuhan Khusus, yang pada umumnya memiliki sejumlah makanan atau minuman pantangan. Mereka tidak begitu saja mengikuti ajakan teman karena kondisi setiap responden berbeda-beda, sehingga pantangannya pun berbeda-beda.

Hampir seluruh responden (92.5\%) memilih produk karena sesuai dengan uang saku. Uang saku responden pada umumnya tergolong besar, dikarenakan pada umumnya uang saku hanya dipakai untuk jajan saja. Demi menjaga asupan makanan dari pantangan, pada umumnya responden dibekali makan siang dan diberikan sarana antar jemput oleh orangtua mereka.

Sebagian besar responden (77.5\%) menyatakan produk yang dipilih adalah produk yang menunjang kesehatan, dengan catatan jika dikonsumsi dalam jumlah sedikit. Mayoritas responden (42\%) memilih produk teh dalam kemasan, sebagian kecil responden $(15 \%)$ memilih produk susu dan $12.5 \%$ memilih minuman ion.

Seluruh responden $(100 \%)$ menyatakan memilih produk yang sesuai dengan kebutuhan. Alasan pemilihan produk antara lain sedang haus, mencari minuman segar, dan sedang mengantuk. Berdasarkan data tersebut di atas, responden cukup memahami kebutuhan diri dan mencari solusi untuk memenuhi kebutuhan tersebut. Bagi responden yang memilih air mineral dalam kemasan memang responden yang sedang sakit, sehingga lebih memilih produk yang aman dan sesuai dengan kebutuhan dirinya.

Hampir seluruh responden (90\%) mengetahui karakteristik produk yang dipilih. Hal ini berkaitan pada data sebelumnya bahwa sebagian besar responden $(75 \%)$ terbiasa membeli produk yang dipilih dalam kesehariannya dan sebesar $87.5 \%$ pernah membeli produk yang dipilih sebelumnya.

Hampir seluruh responden (90\%) tidak memperhatikan komposisi produk yang tertera dalam kemasan walaupun ternyata lebih dari separuh responden (60\%) pernah membaca komposisi produk ketika membeli sebuah produk. Ketika 
dilakukan observasi, hamper seluruh responden memilih produk yang biasa dibeli sehingga tidak tampil kegiatan melihat komposisi produk sebagai bahan untuk mengambil keputusan pembelian.

Lebih dari separuh responden $(62.5 \%)$ tidak melihat katalog produk sebelum memutuskan memilih produk. Sebagian besar responden $(85 \%)$ tidak memilih produk yang sedang promo. Dalam pengamatan sebagian besar responden langsung menuju kepada produk yang disuka tanpa melihat produk yang lain, sebagian responden menimbang memilih produk karena sedang sakit, sebagian responden menimbang memilih produk karena alasan lain. Selain itu, kelompok yang melihat katalog produk sebelum memutuskan memilih produk ialah responden penelitian yang mempunyai uang sakut tidak lebih dari Rp 1.000.000,00/ bulan.

Hampir seluruh responden $(97.5 \%)$ mengetahui produk yang dipilih berdasarkan iklan di TV dan hampir seluruh responden (95\%) merasa mendapatkan informasi dan meyakinkan responden untuk memilih produk. Hal ini menunjukkan bahwa promosi lewat TV adalah promosi yang cukup efektif untuk responden.

Sebagian besar responden (72.5\%) tidak memilih produk yang sedang diskon. Lebih dari separuh responden (62.5\%) tidak membandingkan harga sebelum dan setelah diskon. Sebagian besar responden $(77.5 \%)$ tetap membeli produk yang biasa dibeli walau tidak sedang diskon. Berdasarkan hasil pengamatan, sebagian besar responden langsung menuju produk yang disukai, tanpa melihat promo maupun katalog yang tersedia. Selain itu, sebagian besar responden tidak membandingkan harga sebelum dan setelah diskon.

Lebih dari separuh responden (70\%) mengetahui harga pasaran produk yang dipilih. Hal ini menguatkan pernyataan sebelumnya bahwa produk yang dipilih merupakan produk yang biasa dibeli dalam keseharian. Hampir seluruh responden (97.5\%) menyatakan bahwa harga produk yang dipilih sesuai dengan manfaat yang didapatkan. Seluruh responden (100\%) menyatakan bahwa harga produk yang dipilih sesuai sehingga meyakinkan responden untuk memilih produk tersebut. Hal demikian memperlihatkan bahwa harga yang dipatok cocok dengan harapan yang dipunyai oleh konsumen dari produk tersebut.

\section{Analisis Faktor}

Analisis faktor bertujuan mengidentifikasi, mengelompokkan, dan merangkum faktor-faktor yang memiliki predikat sebagai fenomena, peubah dan dan definsi tertentu. Analisis faktor yang ada di dalam pelaksanaan penelitian adalah analisis faktor per butir pertanyaan, analisis faktor berdasarkan peubah dan analisis faktor berdasarkan sub peubah. 


\section{Tabel 1}

\section{Analisis Faktor Per Butir Pertanyaan}

\begin{tabular}{llc}
\hline NO & \multicolumn{1}{c}{ BUTIR PERTANYAAN } & $\begin{array}{c}\text { NILAI COMPONENT } \\
\text { MATRIX }\end{array}$ \\
\hline 1 & $\begin{array}{l}\text { Saya memilih produk ini karena saya yakin kualitas } \\
\text { produk ini baik }\end{array}$ & $\mathbf{. 5 9 7}$ \\
2 & $\begin{array}{l}\text { Saya memilih produk ini karena menerima kesan yang } \\
\text { baik dari informasi yang didapat }\end{array}$ & $\mathbf{. 5 9 7}$ \\
3 & Saya memilih produk ini karena suka rasanya & $\mathbf{. 5 1 5}$ \\
4 & Saya pernah membeli produk ini sebelumnya dan & $\mathbf{. 7 2 0}$ \\
5 & menyukainya & $\mathbf{. 7 7 9}$ \\
6 & Saya biasa membeli produk ini dalam keseharian & -.096 \\
7 & Saya biasa membeli produk minuman dalam kemasan dimana & .477 \\
7 & Saya membeli produk ini karena pengaruh keluarga (keluarga & -.023 \\
8 & biasa membelinya) & .212 \\
9 & Saya memilih produk ini karena pengaruh teman & -.138 \\
10 & Saya memilih produk ini karena pengaruh media sosial & .402 \\
11 & $\begin{array}{l}\text { Saya memilih produk ini karena sesuai dengan uang saku } \\
\text { menunjang kesehatan }\end{array}$ & .417 \\
13 & saya mengetahui karakteristik produk yang saya pilih & .078 \\
14 & $\begin{array}{l}\text { Saya memilih produk dengan memperhatikan komposisi yang } \\
\text { tertera dalam kemasan }\end{array}$ & -.307 \\
15 & Saya melihat katalog produk sebelum membeli produk & -.522 \\
16 & $\begin{array}{l}\text { Anda lebih memilih produk yang sedang dalam masa } \\
\text { promosi dibandingkan dengan produk yang biasa anda beli }\end{array}$ & .281 \\
17 & Saya mengetahui produk yang saya pilih dari iklan tv, radio & .357 \\
18 & $\begin{array}{l}\text { Iklan produk tersebut memberikan saya informasi dan } \\
\text { membuat saya yakin membeli produk tersebut }\end{array}$ & -.531 \\
19 & Saya memilih produk yang sedang diskon & -.376 \\
20 & $\begin{array}{l}\text { Saya membandingkan harga sebelum dan setelah diskon } \\
21\end{array}$ & $\begin{array}{l}\text { Saya tetap membeli produk yang biasa anda beli walau } \\
\text { tidak sedang diskon }\end{array}$ \\
22 & Anda mengetahui harga pasaran produk yang anda pilih & $\mathbf{. 8 7 3}$ \\
23 & $\begin{array}{l}\text { Produk yang anda pilih memiliki harga yang sesuai dengan } \\
\text { manfaat yang anda dapatkan }\end{array}$ & .191 \\
\hline & & .491 \\
\hline
\end{tabular}

Sumber: Diolah

Faktor yang memperkuat suatu definisi ataupun variabel bilamana mempunyai nilai komponen yang sama atau bahkan lebih tinggi dibanding pada $50 \%$. Berdasarkan data pada tabel di atas faktor-faktor yang mendukung pengambilan keputusan untuk melaksanakan pembelian terhadap produk minuman kemasan untuk mahasiswa dari WNBK PNJ adalah keyakinan akan kualitas produk, kesan yang baik dari informasi yang didapat, menyukai rasa produk, pernah membeli produk tersebut sebelumnya, biasa membeli produk dalam keseharian, dan tetap membeli produk yang biasa dibeli walau tidak sedang diskon. Dapat disimpulkan bahwa contoh merupakan pelaku pembelian rutin untuk produk minuman dalam kemasan. 


\section{Tabel 2}

Analisis Faktor Berdasarkan Peubah

\begin{tabular}{lc}
\hline \multicolumn{1}{c}{ PEUBAH } & NILAI COMPONENT MATRIX \\
\hline Psikologi & $\mathbf{. 8 1 4}$ \\
Pribadi & -.073 \\
Sosial & $\mathbf{. 8 1 1}$ \\
Budaya & .716 \\
Pendukung Lainnya & -.071 \\
\hline \multicolumn{2}{c}{ Sumber: Diolah }
\end{tabular}

Berdasarkan pada tabel yang disajikan tersebut di atas bisa dihasilkan suatu simpulan bahwa peubah yang memberikan pengaruh pada pengambilan keputusan untuk melaksanakan pembelian produk minuman dalam kemasan adalah peubah psikologi, peubah budaya dan peubah sosial. Peubah psikologi dalam penelitian ini antara lain persepsi, motivasi, pengalaman, dan sikap. Peubah psikologi berpengaruh terhadap keputusan pembelian produk antara lain dikarenakan produk yang dipilih merupakan produk yang rutin dibeli oleh contoh.

Menurut (Arbana Syamantha, 2018) menjelaskan bahwa tiap masyarakat memiliki perbedaan kebudayaan dan juga pengaruh dari kebudayaan terhadap perilaku dalam melaksanakan pembelian juga sangat berbeda, dengan demikian distributor dari produk tersebut berupaya untuk mengidentifikasi perubahan kebudayaan atau kebiasaan, oleh karena itu mampu mengidentifikasi suatu produk yang baru yang kemungkinan sangat diperlukan dan dibutuhkan. Menurut (Amri, 2018) menjelaskan bahwa kebudayaan ialah suatu komponen yang dapat menentukan perilaku dan keinginan yang paling pokok dalam memperoleh atau menghasilkan perilaku, preferensi, persepsi, dan nilai yang berasal dari lembagalembaga yang penting lainnya. Faktor kebudayaan menghasilkan sumbangan pengaruh yang dalam dan luas terhadap tingkah laku yang dimiliki oleh konsumen.

Tingkah laku yang ada pada konsumen dari suatu produk dipengaruhi atau diprediksikan dengan beberapa faktor sosial, misalnya ialah status sosial konsumen, serta peran, keluarga, dan juga kelompok kecil. Kelompok referensi didefinisikan sebagai suatu kelompok yang memberikan sumbangan pengaruh secara tidak langsung ataupun secara langsung pada perilaku dan juga sikap yang ada pada seorang individu. Anggota keluarga mampu menghasilkan sumbangan pengaruh dominan pada variabel terikat dari perilaku yang ada pada konsumen. Kedudukan dari seorang individu di dalam suatu kelompok ialah definisi sebagai status dan juga peranan. Tiap peranan menghasilkan suatu status yang merefleksikan pengakuan dari masyarakat yang ada pada individu tersebut (Arbana Syamantha, 2018).

Apalagi contoh adalah warga negara berkebutuhan khusus yang perlu dipantau konsumsi makanan dan minumannya. Beberapa kandungan makanan seperti coklat, tepung ber gluten memberikan pengaruh yang signifikan kepada warga negara berkebutuhan khusus. 


\section{E. SIMPULAN}

Implikasi dari penelitian ini adalah bagi penyedia produk agar mempertimbangkan faktor budaya, sosial, dan psikologis dari konsumen. Bagi warga negara berkebutuhan khusus, terutama untuk usia 18-25 tahun, tren produk dan kelompok acuan sangat memegang peranan penting terhadap pemilihan produk, sehingga pendekatan kepada kelompok acuan sangat penting dilakukan. 


\section{DAFTAR PUSTAKA}

Amri, S. (2018). FAKTOR-FAKTOR YANG MEMPENGARUHI KONSUMEN. Ihtiyath, 2, 149-171.

Arbana Syamantha, N. S. (2018). ANALISIS FAKTOR-FAKTOR YANG MEMPENGARUHI PENGAMBILAN KEPUTUSAN MENGGUNAKAN JASA OJEK ONLINE (GO-JEK). Psikologi Prima, 1(1), 27-38.

Dewanto, A. C., Manajemen, J., Sam, U., \& Manado, R. (2018). PENGARUH BUDAYA , SOSIAL , PRIBADI , DAN PSIKOLOGIS TERHADAP KEPUTUSAN PEMBELIAN SEPEDA MOTOR YAMAHA ( STUDI PADA MAHASISWA FAKULTAS EKONOMI DAN BISNIS UNIVERSITAS SAM RATULANGI MANADO ) THE INFLUENCE OF CULTURE , SOSIAL , PERSONAL , AND PSYCHOLOGICAL TO. EMBA, 6(3), 18781887.

Firman maulana, S. (2016). ANALISIS FAKTOR YANG MEMPENGARUHI KEPUTUSAN PEMBELIAN PADA PASAR TRADISIONAL (Studi Pada Pasar Progo, Desa Tropodo, Waru-Sidoarjo). Jurnal Pendidikan Tata Niaga, 4(1), 1-13.

Ismunandar, Y. A. L. (2019). PENGARUH FAKTOR BUDAYA TERHADAP KEPUTUSAN PEMBELIAN LO'I ME'E MBOJO DI KOTA BIMA. Jurnal Sosial Ekonomi Dan Humaniora, 5(2), 101-111.

Karosekali, A. S., \& Natasha, N. (2018). ANALISIS FAKTOR - FAKTOR KEPUTUSAN PEMBELIAN KONSUMEN MINYAK GORENG PADA MEREK FILMA STUDI KASUS : BRASTAGI SUPERMARKET CABANG GATOT SUBROTO MEDAN . Agriprimatech. Agriprimatech, 2(1), 29-39.

Mindari, E. (2020). ANALISIS FAKTOR-FAKTOR YANG MEMPENGARUHI PERILAKU KONSUMEN DALAM PENGAMBILAN KEPUTUSAN PEMBELIAN PRODUK ROTI ISI KRIM DURIAN (JORDAN BAKERY) DI DESA RANTAU SIALANG KECAMATAN SUNGAI KERUH. Ekonomika, XI(2), 46-61.

Natanael, K. (2020). Pengaruh faktor budaya, sosial, pribadi dan psikologis terhadap keputusan pembelian smartphone xiaomi generasi y di surabaya. Jurnal AGORA, 8(1).

Pinem, L. J. (2018). Analisis Faktor-Faktor Keputusan Pembelian Minyak Goreng Bimoli di Kecamatan Kota Pinang Kab Labuhanbatu Selatan. Agriprimatech, 1(2), 2014-2016.

Prabowo, F. H. E. (2017). ANALISIS FAKTOR YANG MEMPENGARUHI PERILAKU KONSUMEN DALAM MEMBELI PRODUK LAPTOP (Survei Pada Mahasiswa Fakultas Ekonomi Universitas Galuh). Edukasi, 5(2), 165168.

Ruhamak, M. D. (2016). ANALISIS FAKTOR YANG MEMPENGARUHI KONSUMEN DALAM PENGAMBILAN KEPUTUSAN PEMBELIAN 
PRODUK AIR MINUM MERK AQUA (Studi kasus di UD Budi Jaya Kediri). EkoNika, 1(1), 38-49.

Saerang, I. S., Ekonomi, F., \& Manajemen, J. (2017). Pengaruh Kualitas Produk Dan Persepsi Harga Terhadap Keputusan Pembelian Speaker Merek Yamaha Di Fortino Audio Manado. Jurnal EMBA: Jurnal Riset Ekonomi, Manajemen, Bisnis Dan Akuntansi, 6(1). https://doi.org/10.35794/emba.v6i1.18826

Sari, I. P. (2016). Pengaruh Faktor Budaya, Sosial, Pribadi, dan Psikologi terhadap Keputusan Pembelia. Jurnal Manajemen Dan Kewirausahaan, 1(2), 132-142. http://fe.budiluhur.ac.id/wp-content/uploads/2009/07/42-ElizabethGinting.pdf

Suawa, A. J., Tumbel, A. L., \& Mandagie, Y. (2019). ANALISIS FAKTOR FAKTOR YANG MEMPENGARUHI PERILAKU KONSUMEN TERHADAP KEPUTUSAN PEMBELIAN DI NEW AYAM BANDUNG RESTO KAWASAN MEGAMAS MANADO. EMBA, 7(4), 5195-5204.

Timmerman, V. A., Mandey, S., \& Rate, P. Van. (2017). ANALISIS FAKTOR FAKTOR YANG MEMPENGARUHI PERILAKU KONSUMEN TERHADAP KEPUTUSAN PEMBELIAN DI TEXAS CHICKEN MANADO. EMBA, 5(2), 1113-1122.

Widinarsih, D. (2019). PENYANDANG DISABILITAS DI INDONESIA: PERKEMBANGAN ISTILAH DAN DEFINISI. Jurnal Ilmu Kesejahteraan Sosial, 127-142.

Yusra Mauliza Nasution, Iskandarini, H. H. (2018). ANALISIS PERILAKU KONSUMEN KEPUTUSAN PEMBELIAN TELUR PREMIUM OMEGA-3 DI KOTA MEDAN. Journal On Sosial Economic of Agriculture and Agribusiness, $0(8)$. 